\title{
Effect of Technological Parameters on the Heat Transfer Coefficient in Alloy AlCu4Ti using Squeeze Casting Technology
}

Ján Ščury, Richard Pastirčák

Department of Technological Engineering, Faculty of Mechanical Engineering, University of Žilina. Univerzitná 8215/1, 01026 Žilina. Slovak Republic. E-mail: jan.scury@fstroj.uniza.sk, richard.pastircak@fstroj.uniza.sk

The paper deals with the methodology of heat transfer coefficient measuring while using squeeze casting process. The casting with crystallization under pressure was used, specifically direct squeeze casting method. The pressure applied to the melt causes a significant increase (up to ten times) of the coefficient of heat transfer between the casting and the mold. The paper deals also with obtained results of the measured temperatures in the mold and the casting. The goal was to affect crystallization by pressure with value $100 \mathrm{MPa}$. On the basis of the measured variables were calculated values of heat flux between casting/mold, and consequently also the values of heat transfer coefficient.

Keywords: AlCu4Ti alloy, heat transfer coeficient, squeeze casting, heat flux

\section{Acknowledgement}

This work was created in the framework of the project Operational Programme for Research and Development of ITMS code 26220220047. The authors acknowledge the grant agency for support.

\section{References}

[1] JACOB O. AWEDA, MICHAEL B. ADEYEMI (2012). Experimental Determination of Heat Transfer Coefficients During Squeeze Casting of Aluminium, An Overview of Heat Transfer Phenomena, Dr M. Salim Newaz Kazi (Ed.), ISBN: 978-953-51-0827-6, InTech, DOI: 10.5772/52038.

[2] NOVÁ, I., MACHUTA, J. (2013). Squeeze casting results of aluminium alloys. In.: Manufacturing technology. ISSN 1213-2489, Vol. 13, No. 1(2013), pp. 73-79.

[3] RAGAN, E. et al. (2007). Liatie kovov pod tlakom. Vydavatel'stvo Michala Vaška, 2007. 392 s. ISBN 978 - 80 $8073-979-9$.

[4] LEE, J. H., KIM, H. S., WON, C. W., CANTOR, B. (2002). Effect of the gap distance on the cooling behavior and the microstructure of indirect squeeze cast and gravity die cast 5083 wrought $\mathrm{Al}$ alloy. In: Materials Science \& Engineering A, Vol. 338, No.1-2, pp. 182-190, Elsevier.

[5] PASTIRČÁK, R. (2014). Effect of Low Pressure Application during Solidification on Microstructure of Al-Si Alloys. In: Manufacturing Technology, ISSN 1213-2489, Vol. 14, No. 3, pp. 397-400.

[6] BOLIBRUCHOVÁ, D., SLÁDEK, A., BRU゚NA, M. (2010): Effect of filtration on reoxidation proceses in aluminium alloys. Archives of Foundry Engineering. 10(spec. 1), 121-126.

[7] BRŮNA, M., KUCHARČÍK, L. (2014). Progressive method of porosity prediction for aluminium castings. Materials and technology. 48(6), 949-953. UDK 669.715:621.74:620.192.47

[8] VASKOVÁ, I., HRUBOVČÁKOVÁ, M., MALIK, J., EPERJEŠI, Š. (2014). Influence of technological parameters of furane-mixtures on shrinkage creation in ductile cast iron castings. Archives of Metallurgy and Materials. 59(3), 1037-1040.DOI: 10.2478/amm-2014-0174.

[9] BRŮNA, M., KUCHARČÍK, L. (2013). Prediction of the Porosity of Al Alloys. In: Manufacturing Technology. ISSN 1213-2489. Vol. 13, No. 3, pp. 296-302.

[10] BOLIBRUCHOVÁ, D., ŽIHALOVÁ, M. (2013). Possibilities of iron elimination in aluminium alloys by vanadium. In: Manufacturing Technology, ISSN 1213-2489, Vol. 13, No. 3, pp. 289-296.

[11] BREZNIČAN, M., FABIAN, P., MEŠKO, J., DRBÚL, M. (2013). The simulation of influence of quenching temperature on properties of bearing rings. In.: Manufacturing technology. ISSN 1213-2489, Vol. 13, No. 1(2013), s. $20-25$.

[12] KONAR, R., PATEK, M., ZRAK, A. Ultrasonic Testing of Non-ferrous Materials in the Foundry Industry. In: Manufacturing technology, ISSN 1213-2489, Vol. 15, No. 4, pp. 557-562

[13] PODPROCKÁ, R., MALIK, J., BOLIBRUCHOVÁ, D. Defects in High Pressure Die Casting Process. In: Manufacturing technology, ISSN 1213-2489, Vol. 15, No. 4, pp. 674-678 . 